The Crown forests under management in the Province of Quebec comprise 55,000 sq. miles and are subdivided as areas where there are:

(a) working plans in force, $\ldots \ldots \ldots \ldots, 37,100$ sq. miles

(b) working plans under consideration and in preparation $\ldots \ldots \ldots \ldots \ldots \ldots$ revisions $\ldots \ldots \ldots, 3,400$ sq. miles first reports, ... 5,500 sq. miles

(c) working plans inactive $\ldots \ldots \ldots \ldots \ldots$

(d) inventory reports only, (misc. small limits) $\ldots \ldots \ldots \ldots \ldots \ldots \ldots \ldots \ldots \ldots \ldots$

Total

$$
8,900 \text { " " }
$$$$
7,300 \cdots \cdots
$$

1,700 " "

55,000 " "

These working plans are not all first-class material. Few attempts have been made to improve the growing stock, but the plans are at least attempts to establish sustained-yield management. The Forest Service has applied three rules:

(a) No cut is permitted in growing even-aged stands.

(b) Reserves of seed trees by groups, or by a diameter-limit system, are made in mixed stands deficient in softwood regeneration.

(c) A clear cut is applied in all mature and over-mature stands where regeneration of softwoods is assured.

It is economically possible to thin in very accessible young stands, and to log selectively uneven-aged stands where the upper-story has reached maturity. Foresters should not fail to impart this knowledge to those responsible for financing such operations.

\title{
BY W. H. PRICE
}

Puget Sound Section, S.A.F., Weyerhaeuser Timber Co., Tacoma, Wash.

Mr. Price outlined two working circles established by his Company, namely, the Longview Unit and the White River Unit.

In establishing the Longview working circle there was a preponderance of old growth which allowed the mill capacity to be reduced gradually to the allowable cut. In this unit economics was the governing factor. The unit has favourable transportation to the mill which is situated on tide water with good rail connections making operations very economical.

The White River Unit contained a good balance between mature and immature timber and had previously supplied a mill and sustained a town for 40 years.

Mr. Price showed how the objectives of his Company were fulfilled by establishment of Working Circles on a sustained yield basis.

The objectives are to provide:

(1) Capital with a continuous investment.

(2) Labor with continuous and congenial employment.

(3) Society with an uninterrupted supply of forest materials.

\section{By J. G. ROBSON}

\section{B.C. Lumber \&o Shingle Manufacturers' Association.}

Wood is one of man's handiest commodities, it can be used in so many ways and worked so easily. It isn't like steel or some other materials where 